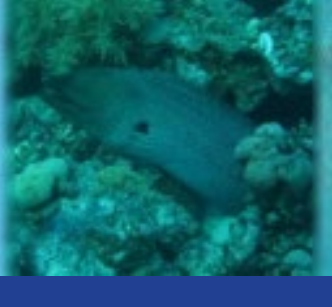

AQUATIC RESEARCH

E-ISSN 2618-6365

\title{
FIRST RECORD OF Jujubinus errinae OUTSIDE OF THE TYPE LOCALITY
}

\author{
Salvatore Giacobbe ${ }^{1}$ (D), Walter Renda ${ }^{2}$ (D)
}

\section{Cite this article as:}

Giacobbe, S., Renda, W. (2019). First record of Jujubinus errinae outside of the type locality. Aquatic Research, 2(3), 170-173.

https://doi.org/10.3153/AR19015

\section{Messina University, Department ChiBioFarAm, Viale Stagno \\ D’Alcontres, 98166 Messina, Italy \\ ${ }^{2}$ Via Bologna 18/A, 87032 Amantea (CS), Italy}

ORCID IDs of the author(s):

S.G. 0000-0002-4619-4862

W.R. 0000-0003-3944-6758

\section{Submitted: 20.07 .2019}

Revision requested: 27.07 .2019

Last revision received: 30.07 .2019

Accepted: 31.07 .2019

Published online: 31.07.2019

Correspondence:

Walter RENDA

E-mail: w.renda1@tin.it

\begin{abstract}
Revision of formerly studied samples showed that the top-shell, Jujubinus errinae Smriglio et al., 2016, known so far only from the Strait of Messina, also occurs in the Ustica seafloors, southwestern Tyrrhenian Sea. Both areas are characterized by Laminaria rodriguezii kelp beds, which may represent an Atlantic-like habitat hosting J. errinae together with other benthic species having in the Strait of Messina their type locality.
\end{abstract}

Keywords: Mollusk, Mediterranean, Laminariales, Biogenic seafloor, Biogeography 


\section{Introduction}

The recently described top-shell, Jujubinus errinae Smriglio et al., 2016, is known so far only from the type locality, the Strait of Messina, an area that is recognized as a hotspot of biodiversity hosting numerous presumed endemism. In the eventuality that $J$. errinae might occur in other Mediterranean districts, samples of Jujubinus collected elsewhere in related habitats were reexamined and related published and unpublished data carefully revised.

Aim of the paper is to report the second finding of this poorly known species, suggesting more extensive investigation on the Mediterranean bioclastic environments.

\section{Material and Methods}

Kelp bed communities and related death assemblages have been described by Di Geronimo et al. (1988) from the "Apollo Bank", south-western Tyrrhenian Sea. The bank, belonging to the Ustica volcanic system, has a $40 \mathrm{~m}$ shallower depth, reaching $-150 \mathrm{~m}$ towards the $3 \mathrm{~km}$ distant Ustica Isle (Figure 1). A dense Laminaria rodriguezii Bornet 1888 kelp forest characterizes the rocky floors, locally covered by biogenic gravelly sediments, which testify of a strong current regime. A $7 \mathrm{dm}^{3}$ sample of sediment, dredged from $70 \mathrm{~m}$ to 50 $\mathrm{m}$ depth, has been sieved on $1 \mathrm{~mm}$ mesh and entirely examined.

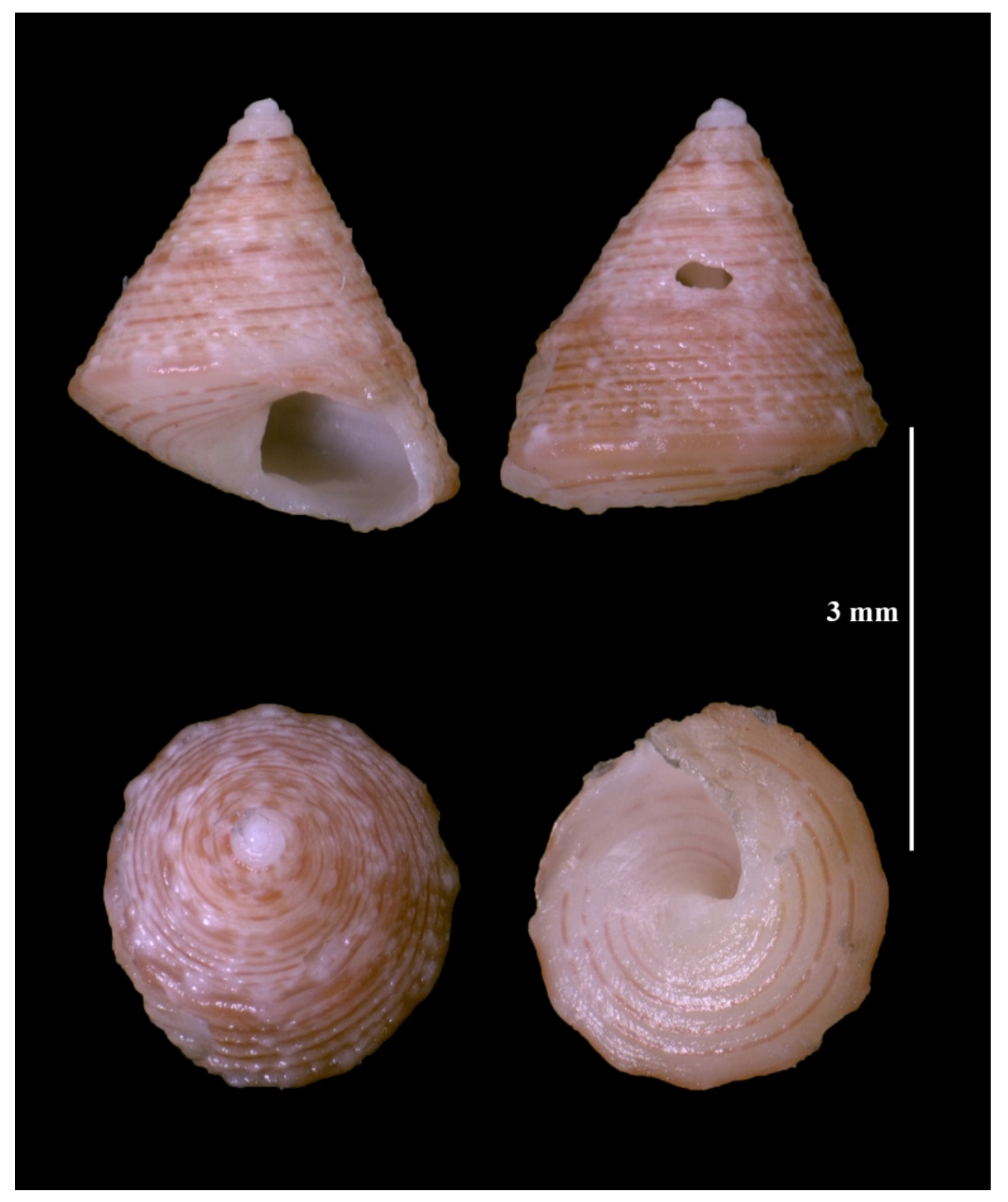

Figure 1. Four views of Jujubinus errinae entire specimen from Ustica. The cephalopod predation hole is recognizable. 


\section{Results and Discussion}

The mollusc death assemblages, deposited at the Messina University Benthic Ecology Laboratory, provided a specimen (BEL137BA1988Je1) (Figure 2) and two incomplete shells of this species (BEL137BA1988Je2/3), formerly classified as Jujubinus elenchoides (Monterosato) (sic). The complete specimen, $3 \mathrm{~mm}$ height, showed a small elliptical hole indicating cephalopod predation, while the fragmented shells indicated durophagous fish predation.

The Strait of Messina, type locality of $J$. errinae, is a complex and diversified area of tidal-induced upwelling, whose nutrient enrichment and temperature lowering support peculiar "Pliocene Atlantic remnants", as wide kelp beds and dense colonies of the Hydrozoan Errina aspera (Linnaeus, 1767) (Smriglio et al., 2016).

In agreement with Di Geronimo et al. (1988), contamination by shallower levels in the Apollo Bank may be excluded, suggesting that the species is linked to the habitat in which it was

\section{Banco Apollo -}

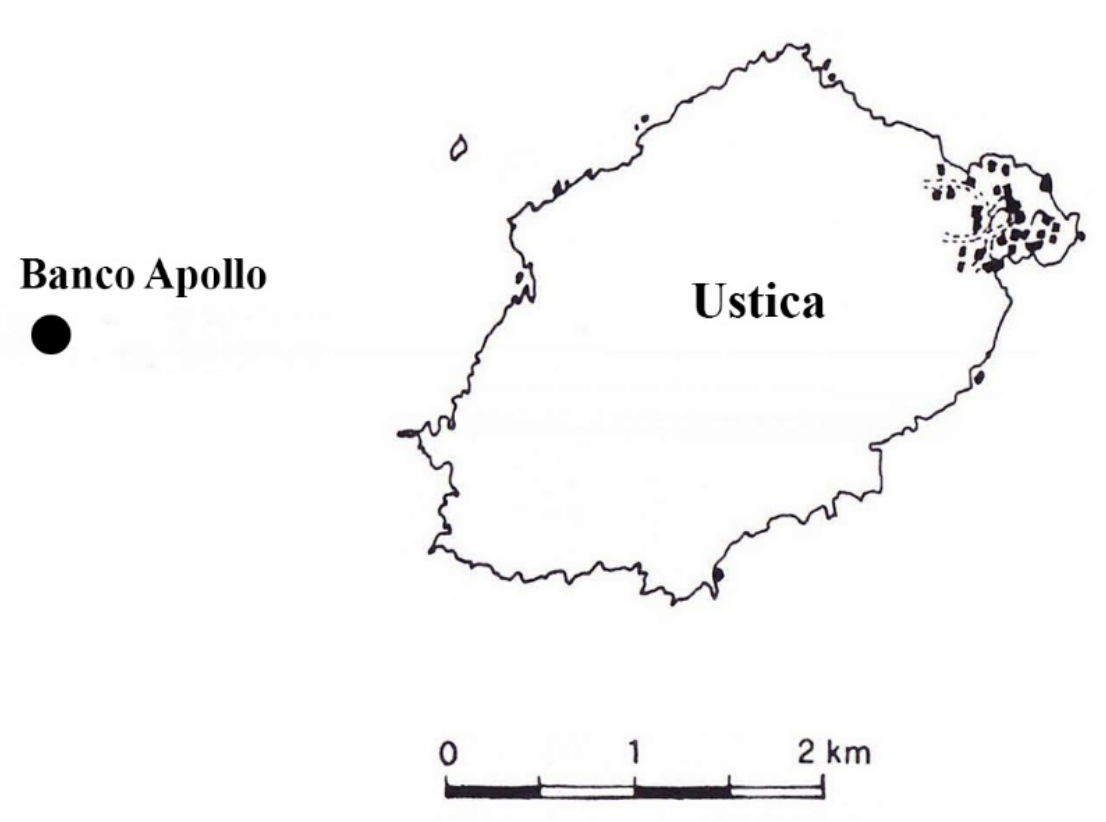

collected. The initial hypothesis that $J$. errinae might represent an accessory species in the Errina aspera assemblages (Smriglio et al., 2016), should be thus implemented, including this species in those kelp bed communities known to give a marked "Atlantic" connotation to the Strait of Messina (Assis et al., 2016), and recognizable in other localized Mediterranean sites, as recently suggested for the polyplacophoran Callistochiton (Allerychiton) pachylasmae (Monterosato, 1869), also having the Strait of Messina as type locality (Dell'Angelo et al., 2018).

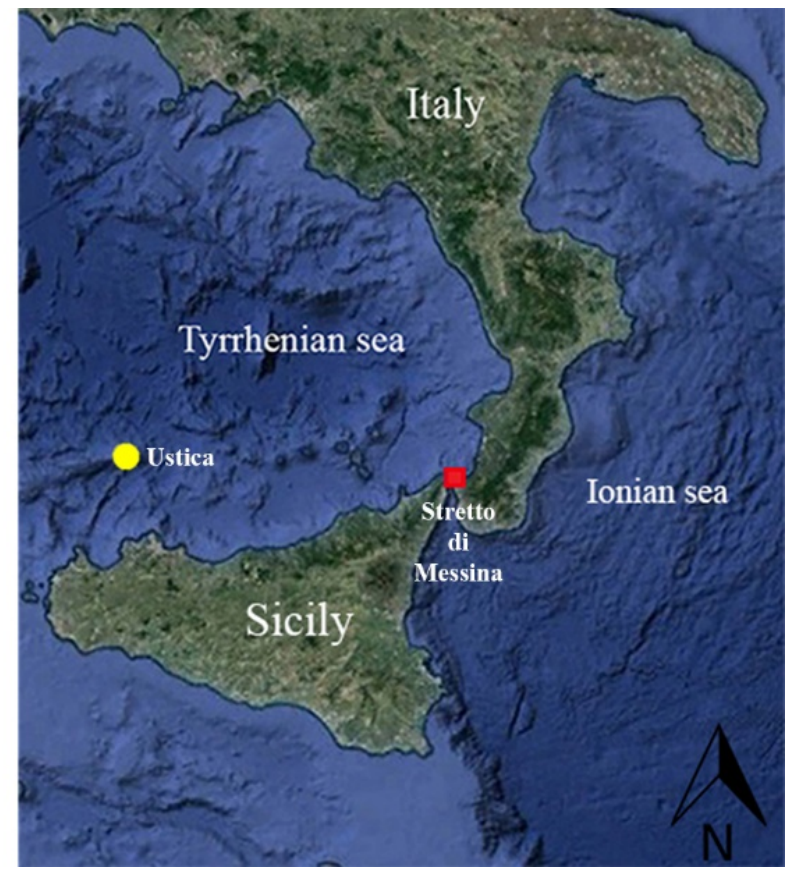

Figure 2. Sampling stations of Jujubinus errinae (modified from Di Geronimo et al., 1988). 


\section{Conclusion}

The report of Jujubinus errinae from Ustica Island is a further indication that Mediterranean biogeography is more articulated and complex than currently described; in this respect, more extensive investigations on habitats that are still considered marginal, and an accurate revision of deposited samples, will might provide important contributions.

\section{Compliance with Ethical Standard}

Conflict of interests: The authors declare that for this article they have no actual, potential or perceived conflict of interests.

\section{References}

Assis, J., Coelho, N.C., Lamy, T., Valero, M., Alberto, F., Serrão, E.A. (2016). Deep reefs are climatic refugia for genetic diversity of marine forests. Journal of Biogeography, 43, 833-844.

https://doi.org/10.1111/jbi.12677
Di Geronimo, I., Giacobbe, S., Rosso, A., Sanfilippo, R. (1988). Popolamenti e tanatocenosi del Banco Apollo (Ustica, Mar Tirreno meridionale). Atti IV Simposio di Ecologia delle Comunità Bentoniche, Sorrento, 1-5 novembre. Museo Regionale di Scienze Naturali - Torino: 697-729.

Dell'angelo, B., Renda, W., Sosso, M., Giacobbe, S. (2018). 138 years later: new data on Callistochiton (Allerychiton) pachylasmae (Monterosato, 1879) from its type locality: the Strait of Messina. Archiv für Molluskenkunde, 147(2), 215221.

https://doi.org/10.1127/arch.moll/147/215-221

Smriglio, C., Mariottini, P., Giacobbe, S. (2016). Jujubinus errinae n. sp. (Gastropoda trochidae) from the Strait of Messina, Mediterranean Sea. Biodiversity Journal, 7(1), 59-66. 